Revue d'histoire de l'Amérique française

REVUE D.HISTOIRE DE L'AMÉRIQUE FRANÇAISE

\title{
A Mirage: The Sea of the West (part II) \\ Jean Delanglez
}

Volume 1, numéro 4, mars 1948

URI : https://id.erudit.org/iderudit/801414ar

DOI : https://doi.org/10.7202/801414ar

Aller au sommaire du numéro

Éditeur(s)

Institut d'histoire de l'Amérique française

ISSN

0035-2357 (imprimé)

1492-1383 (numérique)

Découvrir la revue

Citer cet article

Delanglez, J. (1948). A Mirage: The Sea of the West (part II). Revue d'histoire de l'Amérique française, 1(4), 541-568. https://doi.org/10.7202/801414ar d'utilisation que vous pouvez consulter en ligne.

https://apropos.erudit.org/fr/usagers/politique-dutilisation/ 


\section{A MIRAGE: THE SEA OF THE WEST}

\section{PART II}

It may safely be said that the man who in the eighteenth century exercised the greatest influence on the search for the Sea of the West was Claude Delisle, the foremost geographer of his day, and the reformer of cartography ${ }^{1}$. Since this honor is usually attributed to his son Guillaume, it is necessary to prove the above statement which might be challenged on the ground that the memoirs and maps are all signed by Guillaume Delisle; as we shall see, while the voice is Guillaume's, the ideas are Claude's.

Claude Delisle was born at Vaucouleurs (Lorraine) in November 1644. He made his studies at the Jesuit College of Pont-à-Mousson. His father wanted him to be a lawyer, but the bar had no attraction for him, and he soon devoted himself wholly to the study of history and geography. To pursue these studies he went to Paris, and earned a living by giving private lessons in both disciplines. He was so successful and his reputation was such that the most prominent people sought his services, having among his pupils the Duke of Orleans who later became Regent. In 1718, he suffered an apoplectic attack that left him paralyzed until his death in $1720 .^{2}$

In 1674, he married Nicolle-Charlotte Millet de la Croyère, who bore him four sons and a daughter. Two of his sons achieved great distinction, the eldest Guillaume (1675-1726) as a geographer, and the third Joseph-Nicolas (1688-1768) as an astronomer.

I have shown elsewhere that the general belief that all the maps signed by Guillaume Delisle were made by him, was erroneous; and

1. C. SANDler, Die Reformation der Kartographie um 1700 (Munich and Berlin 1905), $14 \mathrm{ff}$.

2. J. P. Nicenon, Mémoires pour servir à l'histoire des hommes illustres dans la république des lettres (43 vols, Paris 1729-1745), 1: $214 \mathrm{ff}$. 
I have also shown that the author of the first maps - that is, those published between 1700 and 1703 - and signed by Guillaume, were actually the work of his father ${ }^{3}$. We shall now proceed to show that the early memoirs dealing with the Sea of the West were written by Claude, that Claude, not Guillaume, drew the first maps on which such a sea appears. In this case, as in the case of maps published between 1700 and 1703, it was the name of Guillaume which was before the public, ${ }^{4}$ but he was merely expounding his father's geographical theory, which he was just as thoroughly convinced would prove to be right.

The Delisle papers which we shall used extensively in the second part of this article are in volume 115 of the Archives du Service Hydrographique, Paris, ${ }^{5}$ a volume composed of thirty-seven cartons forming a sub-series known as "Manuscrits Delisle. " These cartons "sont en réalité des volumes in folio et comprenant chacun des liasses renfermant un nombre variables de pièces... Sur chaque pièce se trouve écrit de la main de Delisle le numéro du portefeuille, le numéro de la liasse dans le portefeuille, et une lettre indiquant la place de la pièce dans le portefeuille. $)^{6}$

One of these boxes, ASH, 115-11: no. 12, contains the following five pieces:

A) Conjectures sur l'existence d'une mer dans la partie occidentale (de la Nouvelle France) du Canada et du (fleuve) Mississipi dez le temps de M. de la Salle. Par Claude Delisle.

B) Sur la Decouverte que l'on a faite dans ces derniers temps de

3. "The Sources of the Delisle Map of America, 1703, "Mid-America, 25 (1943): 276-280.

4. "Car dans cette famille [the Sanson family], on a toujours exactement observé de mettre les noms des Auteurs aux Ouvrages, sans les confondre, \& sans qu'un fils par exemple, ait voulu se dire Auteur de l'Ouvrage de son père, pas même par un contrat, quoique cela ait été mis en usage par d'autres." Niceron, Mémoires pour servir à l'histoire des hommes illustres, 13: 211.

5. All the documents anterior to 1789 , which were in this depot, were transferred in the autumn of 1947 to the Archives Nationales; the maps of ASH antedating the Revolution, were deposited in the Bibliothèue Nationale. Letter of Father John A. Kemp. Commandant Jearnay in charge of the maps assured Father Kemp that the classification of ASH would be kept.

6. A. IsNaRD, « Joseph-Nicolas Delisle, sa biographie et sa collection de cartes géographiques à la Bibliothèque Nationale \#, Bulletin de la Section de Géographie, 30 (1915): $59 \mathrm{f}$. 
la Riv de Mississipi et du Grand pais de la Louisiane. Par Claude Delisle.

C) Preuves du voisinage de la Nouvelle France avec le Nouveau Mexique et de l'existence d'une mer dans la partie occidentale de cette meme Nouvelle France. Par Claude Delisle.

D) Preuves de l'Existence d'une mer à l'occident de la Nouvelle France et d'un detroit pour aller de la baye d'Hudson à la Mer Pacifique.

E) Des Decouvertes qui ont été faites dans l'Amerique Septentrionale aux environs de la gr. Riv. de Mississipi dont a a pris possession au nom de Sa Mte et des Observations qu'on y a faites.

We shall now prove that the memoir presented by Guillaume Delisle to the government sometime in 1718 , is that written by his father in $1703^{8}$. In 1753 , Joseph-Nicolas Delisle published a book entitled Nouvelles Cartes des Decouvertes de l'Amiral de Fonte, in which he says:

La connoissance de la Mer de l'Ouest, qui est une Mer particulière située à l'Ouest du Canada, au Nord du nouveau Mexique \& au Midy des Terres découvertes par l'Amiral de Fonte, est d'une trop grande conséquence, dans la recherche du passage à la Mer du Sud, pour ne m'être pas trouvé engagé à publier tout ce que j'en ai appris; j'en ferai un article à part, J'y rapporterai tout ce que feu mon Frère le Géographe avoit recueilli de témoignages \& d'autorités pour en prouver l'existence...

J'ai trouvé, parmi les papiers de mon Frère plusieurs copies de son Mémoire pour prouver l'existence de cette Mer; elles étoient plus ou moins étendues suivant le dessein qu'il a toujours eu d'en faire usage. Et effectivement, il l'a présenté aux Ministres et autres Personnes de considération, afin d'exciter à la recherche de cette Mer à de nouveaux voyages faits exprès dans l'intérieur du Canada ou aux autres endroits qui auroient pû y conduire. Mon Frère étant mort, avant d'avoir publié son Mémoire, \& sans avoir eu la satisfaction d'apprendre que l'on l'eût confirmé \& perfectionné, j'ai jugé à propos de le faire imprimer sur un Exemplaire fort au net qu'il avoit présenté au Ministre qui avoit la Marine dans son Département.

7. Joseph-Nicolas Delisle wrote on the top of this document: « Memoire preparé par mon Père en 1702 pour servir de fondement à celui que mon frere vouloit bien lire à l'Académie. "

8. Bobé to Delisle (after July 9, 1718), ASH, 115-10: no. 26 A; and April 30 1718, ibid., J. 
Cet Exemplaire qui est double, se conserve au Dépôt des Cartes \& Plans de la Marine...?

This Guillaume Delisle original does not seem to be in ASH (formerly Cartes et Plans de la Marine), but there exists a contemporary copy made before 1727. ${ }^{10} \mathrm{~A}$ line for line comparison between ASH, $115-11 ;$ no. $12 \mathrm{~A}$ and this copy shows that these two copies are nothing else than copies of that published by Joseph-Nicolas Delisle. Naturally, some changes demanded by circumstances had to be made. For instance Claude Delisle writing in 1703 begins thus:

Le Roy ayant témoigné qu'il avoit a cœur la découverte de la partie occidentale de la Nouvelle France, j'ai cru que je ferois une chose agréable à S.M. si je donnois quelques lumières pour cette découverte, en montrant qu'il y a une mer dans ces endroits là...

The opening lines of the memoir handed in by Guillaume Delisle to the minister in 1718 read as follows:

Le feu Roy Louis $X I V$ ayant toujours témoigné qu'il avoit à coour j'ai cru que je ferai une chose utile à l'État, si je donnois...

It is manifestly out of the question to give all the variants, for it would mean to give a critical text of the entire document. One more instance will suffice.

\section{Claude Delisle}

Nicolosi, dans son Hercule Sicilien marque aussi une Mer au Nord du Nouveau Mexique, sur laquelle il a placé Quivira. Je ne sçai s'il a u d'autres memoirs que ceux dont je me suis servi, mais [M. l'Abbé Bernou, the name is deleted; instead there is an addition in pencill on m'a assuré qu'il avoit eu communication de ceux que l'on envoie à la Congregation de la Propagande

\section{Guillaume Delisle}

Nicolosi, dans son Hercule Sicilien, marque aussi une Mer au Nord du Nouveau Mexique, sur laquelle il a placé Quivira. Je ne sçai quels sont les Mémoiresqu'ils a suivis; mais on m'a assuré qu'il avoit eu communication de ceux que l'on envoye à la Congrezation de la Propagande.

9. J.-N. Delisle, Nouvelles Cartes des Decouvertes de l'Amiral de Fonte (Paris 1753), $4 \mathrm{f}$.

10. This copy is in the second of four similarly bound volumes bearing the following inscription on the front cover: « $\mathrm{A}$ la Substitution du Valdec proche Soleure en Suisse, MDCCXXVII, in the E.E. Ayer Collection of the Newberry Library, Chicago, p. 133-149. 
From a document in the hand writing of Claude Delisle, we know that the Abbe Bernou here mentioned had supplied him with memoirs and maps. ${ }^{11}$ We can surmise what happened. Although Guillaume Delisle had also written in 1703 a memoir to "prove " the existence of the Sea of the West, ${ }^{12}$ when it came to present it to the authorities in Paris, he preferred to copy that of his father, and handed it in as his own.

Besides the fact that the document quoted above is in the handwriting of Claude Delisle, there is positive evidence that he is the author of it. In March 1700, seven maps were published in Paris under the name of Guillaume Delisle, among which was a mappemonde very similar to another mappemonde published six months earlier by Jean-Baptiste Nolin, who had the title of " géographe ordinaire du Roi. ") From the great similarity of the two mappemondes, it was immediately apparent that one had copied the other. ${ }^{13}$ Throughout 1700,1701 , and 1702, the claims and counterclaims of Delisle and Nolin appeared in the Mémoires de Trévoux and in the Journal des S çavans, but in those days as in ours, letters to the editors never solved anything. After the first few letters, one party - usually that who is in the wrong - started being heavily facetious and ended by calling the other names.

Right from the beginning, Delisle had proposed that a conference be held " par devant des Experts et des gens du métier "; and that both contestants would have to "répondre aux demandes qu'ils se feroient l'un à l'autre, ou qui leur seroient faites par les Arbitres; et enfin de rendre comte de la construction de sa Carte, et que celui des deux qui ne pourroit le faire, fut contraint d'avouer qu'il a copié l'autre, et de biffer sur sa planche, ce qu'il s'est faussement attribué.) ${ }^{14}$

11. "The Sources of the Delisle Map of America 》 Mid-America, 25 (1943): 284 f, 296 f.

12. Supra, ASH, 115-11: no. $12 \mathrm{D}$.

13. "Reponse de M. Delisle à la Plainte de M. Nolin ", Journal des Sçavans, July 5,1700 , p. 273. - Here as well as in several other articles published in the Mémoires de Trevoux and in the Journal des Sçavans, it is not said which Delisle, Claude or Guillaume, is speaking, but from several passages it is clear that it is Claude. Cf. " Seconde lettre du S. Nolin, Geographe ordinaire du Roi \& de Son Alt. Royale Monsieur, 》 ibid., August 2, 1700, p. 297; " Reponse de M. Delisle à la seconde lettre de M. Nolin, " ibid., 318.

14. "Reponse de M. Delisle à la Plainte de M. Nolin, " ibid., 274. Cf. " Reponse de M. Delisle à la seconde lettre de M. Nolin, ibid., 317. 
Nolin, whose conscience was not clear, ignored this means of putting an end to the controversy. In 1702, Guillaume Delisle became a member of the Académie des Sciences, and joined his father in the fight with Nolin; for it was his name which appeared on the map. On April 26, 1706, the king's council ordered the two parties to choose experts who would study the question and decided who had plagiarized the other. From their number Guillaume Delisle and Nolin agreed on two mathematicians as judges of the controversy: Joseph Sauveur and François Chevalier, both of the Académie des Sciences. ${ }^{15}$

The maps handed over to the experts, the method by which they unmasked the plagiarist, their own controversy with Nolin after they convicted him of crass ignorance, make absorbing reading but would lead us too far afield, and moreover, would be out of place in this article. Suffice it to say that on July 19, 1706, Sauveur and Chevalier declared:

Après avoir preté serment entre les mains de Monsieur Turgot Rapporteur de l'Instance, \& avoir duement examiné lesdites Cartes \& les autres pieces jointes au procès, [sont] d'avis sous le bon plaisir du -Roy \& de Nosseigneurs de son Conseil, Que le Globe gravé du sieur de l'Isle, \& les six Cartes generales qu'il a publiées en même temps, ou les originaux MS desdits Ouvrages dudit de l'Isle, ont été contrefaits par le sieur Nolin dans sa Mappemonde de 4 feuilles qu'il a publiée en $1700 .^{16}$

The reports of the experts is especially important because of the light which it throws on the authorship of the maps which appear under the name of Guillaume Delisle, and in the present case, because it enables us to establish the authorship of the memoir entitled " Conjectures sur l'existence d'une mer dans la partie occidentale du Canada et du Mississipi dez le temps de M. de la Salle. " Even though, say MM. Sauveur and Chevalier, some features which appear on Nolin's map, but are not on Delisle's printed mappemonde, these features were on the latter's manuscript globe which the former found some way of copying.

Parmi les choses qu'il [Nolinl avoit prises dudit de l'Isle, et dont il il se disoit neanmoins l'auteur, est la Mer de l'Ouest à l'occident de

15. Arret portant que les cartes des Srs Nolin et Delisle seront examinées, April 26, 1706. BN, Mss. fr., 22119: $181 \mathrm{f}$.

16. BN. Mss. fr., 22119: 185, p. 4 of the printed copy. 
la Rivière de Mississipi. Il disoit qu'elle ne se trouvoit sur aucune Carte, que de l'Isle ne la connoissoit pas, \& que sans sa mappemonde il n'y auroit jamais pensé. On jugera de cette allegation par le Certificat suivant.

Je soussigé certifie que lorsque je menai M. de l'Isle a feu M. le Chancellier, pour lui presenter un Globe MS de sa façon, M. le Chancelier se faisant montrer ce qu'il pouvait $y$ avoir de nouveau sur ce globe, ledit sieur de l'Isle lui fit remarquer entr'autres choses singulières et nouvelles une Mer au dela de la Riviere de Mississipi, qu'il appeloit Mer de l'Ouest, \& qui etoit marquée sous ce nom sur ledit Globe MS par laquelle il prétendoit qu'on pourroit tirer de l'avantage pour le commerce de la Chine et du Japon: En foi de quoi j'ai signé le present certificat, pour servir audit de l'Isle à te!le fin que de raison. Fait à Paris le 8 juillet 1706. Signé, B.-H. de Fourcy, Abbé de Saint Vandrille.

Quand de l'Isle présenta ce Certificat à ses Juges, le sieur Nolin qui étoit présent dit qu'il n'avoit jamais douté qu'il ne fut sur son Globe MS. On peut par là juger de sa bonne foi, ayant dit ci-devant que de l'Isle ne la connoissoit pas, \& que sans lui il n'y auroit jamais pensê. ${ }^{17}$

The " $M$. de l'Isle » mentioned in the certificate is Claude Delisle; the "Chancelier ) is Louis Boucherat, comte de Compans; and the time is $1696^{18}$. A Sea of the West is shown on all the drafts, ${ }^{19}$ but neither he nor his son inscribed it on their printed maps. 20 JosephNicolas Delisle, however, did not admit this, and throughout his book he attributes to his brother what was really the work of his father.

We now come to the memoir itself which, as we shall see, contains the texts quoted in the first part of this article. Claude Delisle begins thus:

( Comme la preuve de ma proposition dépend en partie de la situation de Quivira, la première chose que je crois devoir établir est cette

17. Ibid., 187, page 8 of the printed copy.

18. "Reponse de M. Delisle à la Plainte de M. Nolin ", Journal des Scavans, July 5, 1700, p. 273.

19. Cf. AN, JJ, 75-128, 130, 253; ASH, 140-4; BSH, C 4040-4, B 4049-32; AN, JJ, 75-154, 1702.

20. Cf. the globe of 1700 in Frontières entre le Bresil et la Guyane Francaise (Paris 1899), no. 87; the mappemonde of 1700 in Sandler, Die Reformation der Kartographie; the map of 1700; that of 1703 in Paullin; that of 1720 in Sandler; that of 1722. 
gituation. ") [What follows is a brief summary of the first part of Claude Delisle memoir entitled]: " Preuves du voisinage de la Nouvelle France avec le Nouveau Mexique et de l'existence d'une mer dans la partie occidentale de cette meme Nouvelle-France, ) or pièce C of no. 12.

The existence of a sea washing the shores of Quivira is proved by texts from Lopez de Gomara, ${ }^{21}$ De Laet, ${ }^{2}$ and Ramusio. ${ }^{2} 3$

"Il y a de l'apparence que ce qui a rendu cette Mer si peu connue, a été le soin que les [autres nations, these words are deleted in $\mathrm{A}$, and do not appear at all in A-1] Espagnols ont pris de la cacher aux autres Nations de l'Europe. ") The English, for instance, have had some knowledge of this sea, as can be seen in Purchas $;^{24}$ and Delisle find this confirmed by what is said in the Relation of $1640^{25}$. " Mais s'il est vrai de dire qu'il y ait une mer en cet endroit si voisine de la Nouvelle france, d'où vient que les François qui sont établis dans ce pais la n'ont en point $u$ de connoissance ${ }^{26}$ Je réponds à cela, qu'il y a longtemps qu'ils en ont u des avis; mais que la négligence ou peut-être la difficulté, les a empêchés de s'en servir. )

Claude Delisle than proceeds to give texts from the Jesuit Relations with which he was thoroughly familiar, for he had previously made a series of sketches expressing cartographically the information contained in the Relations. ${ }^{27}$ It will suffice to list those texts and give the reference to Thwaites' edition, leaving to the reader to determine whether they prove the existence of a sea in the west of New France. The first Relation from which he quotes is that of $1632 ;{ }^{28}$ the next $2: 231 \mathrm{ff}$.

21. F. Lopez De Gomara, Historia General de la Indias (2 vols., Madrid 1932);

22. J. De LaEt, L'histoire dv Nouveau Monde ou Description des Indes Occidentales Contenant dix-huict liures (Leyden 1640), 218.

23. G. B. Ramusio, Delle Navigationi et Viaggi (3 vols., Venise 1606), 3: 302.

24. S. Purchas, Hakluytus Posthumus or Purchas His Pilgrimes (20 vols. Glasgow 1906), 19; $122 \mathrm{ff}$.

25. JR, 18: 234-236. On this text see "The Voyage of Louis Jolliet to Hudson Bay in 1679, " Mid-America, 26 (1944): 222.

26. The text (A-1) of Guillaume Delisle reads: "Mais comment, me dira-t-on, peut-il y avoir une Mer si voisine de la Nouvelle France, sans que les François qui y sont établis, en ayent eu connoissance? "

27. "The Sources of the Delisle Map of America», Mid-America, 25 (1943): 283.

28. JR, 5: 184. 
that of $1641 ;^{29}$ then comes the Relation of $1659-1660 ;{ }^{30}$ and concludes: "Or cette mer, qu'ils trouvent à l'ouest, ne peut être que celle dont je parle. " After summarising two passages in the Relation of 1669 $1670,{ }^{31}$ he comments as follows.

Quojque ces deux témoignages soient plus précis que les précédents et parlent plus positivement de la mer d'Ouest, je ne voudrois pas néanmoins y appuier beaucoup parce que je suis presque persuade que c'étoit de la Baye d'Hudson dont les Sauvages entendoient parler à ces Pères [Marquette and Dablon], a cause qu'aux Assinipoils il y a effectivement une Riviere qui se rend dans cette Baye, et d'ailleurs les Assinipoils ne sont pas aujourd'hui dans la situation que le P. Marquette leur donne. ${ }^{32}$

What he says in this paragraph is quite true, but Dablon who was just as anxious as Delisle to prove the existence of a sea in the West of New France, interpreted the text differently. After taking note of what is said in the Relation of $1666,{ }^{3}{ }^{3}$ he passes to other texts:

"Ceux qui ont travaillé ces derniers temps à la découverte de la Rivière de Mississipi, ont aussi ouï parler de cette mer. Le Sr Joliet qui fut envoyé l'an 1673, par M. de Frontenac pour f [air]e cotte découverte, a son retour présénta une carte dont $j$ 'ai la copie ${ }^{34}$ sur laquelle il a écrit que par une de ces grandes Rivières qui vient de l'ouest... 1) $)^{35}$

The next paragraph begins thus:

" Le Père Marquette que j'ai cité ci-dessus et qui étoit avec led. Joliet dans cette découverte, parle plus précisément du chemin, car il dit dans sa Relation que les Sauvages l'avoient assuré que quand

29. JR, 21: $200 \mathrm{f}$.

30. Supra, $355 \mathrm{f}$.

31. JR, 54: 136, cited supra, $358 \mathrm{f}$; and 54: 192. In the latter passage, Dablon merely elaborated on Marquette's letter.

32. This passage was crossed out by Claude, and does not appear in the memoir of Guillaume.

33. JR, 51: 540 .

34. This copy had been given to Claude Delisle by the Abbe Bernou, "The Sources of the Delisle Map of America, " Mid-America, 25 (1943): 285. - On this map, cf. " The Jolliet Lost Map of the Mississippi, „ ibid., 28 (1946): 90 f; Life and Voyages of Louis Jolliet, 80.

35. On this inscription, ef. "The Discovery of the Mississippi. Primary Sources, Mid-America, 27 (1945): 227 f, 230; and supra, 364. 
on a remonté pendant cinq ou six jours la Rivière des Osages ou des Missouri, on trouvoit une belle prairie... $)^{36}$

Delisle had read this passage in the narrative published by Thévenot, ${ }^{3}$ and he could not know that its author was not Marquette, but Dablon who is expressing his own conceptions of western geography. 38

After Jolliet and Marquette, the memorialist passes to La Salle who was " accompagné par deux Recollets, le P. Zenobe et le Père Hennepin, qui ont tous deux parlé de cette mer. " He then quotes 'from the Premier Etablissement de la Foy, which we gave in the first part of this article; ${ }^{39}$ and made use of the Nouveau Voyage, ${ }^{40}$ where Father Hennepin offers to find " un passage commode, pour nous rendre des terres de nôtre Louisiane, dans la Mer pacifique, par des Rivieres qui portent de gros Vaisseaux, situées au dela du fameux Fleuve de Meschasipi. ) 41

At this point Delisle advances two testimonies which we did not mention in the first part of this article. The first is the map of Louvigny ${ }^{4}$, " qui a commandé en Canada pendant plusieurs années, faite par lui sur ses propres connoissances, et sur les Relations de plusieurs François qui étoient allés avec M. de la Salle. Sur cette carte, il marque aussi une Riviere (a peu près comme je fais, the words italicized are

36. JR, 59: 142.

37. Recueil de voyages de Mr. Thevenot (Paris 1681), $30 \mathrm{f}$; and cf. iThe Sources of the Delisle Map of America, "Mid-America, 25 (1943): 285.

38. "The Récit des voyages et des découvertes du Père Jacques Marquette \#, Mid-America, 28 (1946): 242 ff.

39. Supra, 369.

40. The differences between Claude's text, A, and Guillaume's, A-1, can be shown by placing into ( $)$ what is in A and not in A-1, and into [ ], what is in A-1 and not in A. (Enfin) le P. Hennepin (Recollet qui avoit accompagné M. de la Salle pendant plusieurs années et qui par chagrin contre ses superieurs s'en retira) [qui s'est retiré en] Angleterre et [ensuite] en Hollande dans l'histoire qu'il a faite de cette découverte par ordre (du) [de Guillaume III] Roi d'Angleterre, et des Ettats Generaux, (se promet) [assure que] si on veut le renvoyer dans ce pais la il trouvera un passage commode... "

41. Supra, 373. - Farther down in his memoir Delisle wrote: « Le P. Hennepin dit que les grande vues de M. de la Salle ne rouloient que sur l'expérance qu'il avoit de trouver la mer Pacifique. "We have discussed Hennepin's assertions concerning "les grandes vues de M. de la Salle. »

42. BSH, C 4040-10; reproduced in S.J. Tucker, Indian Villages of the Illinois Country, Part I, Atlas (Springfield 1942), pl. XIV. 
crossed out, and they do not appear in A-1) qu'il appelle la Rivière de l'ouest. Il dit qu'elle coule du côté des Espagnols, et qu'elle tombe dans la mer, ajoutant que c'est par la que les sauvages de ces quartiers vont piller les Espagnols. " ${ }^{43}$ Aside from the fact that Delisle says more than the inscription on the map, it is difficult to see what was added by it. The date of Louvigny's map is 1697 , and he was merely expressing what was thought in Canada; namely, that there was a river that flowed into the Sea of the West.

The other testimony is that of Pierre-Charles Le Sueur.

J'ai appris de M. le Sueur qui a demeuré long temps chez les Sioux, que les Panis habitent sur un lac, d'où sort une grande Rivière nommée Meschasipi, ${ }^{44}$ qui coule vers ]'ouest sans qu'on sçache où elle va. Il est probable que cette rivière est la même que celle dont le P. Marquette a parlé ci-devant et qu'elle se va jetter dans la Mer qui ne doit pas être éloignée de ces endroits, puisque le même $M$. le Sueur m'a dit aussi que les Sioux étoient un jour allés à 15 journées vers l'ouest, pour faire la guerre a des nations qui leur étoient ennemies et qu'ils trouvèrent dans ce pays des forteresses sur le bord de la mer, dans lesquelles ils virent des gens habillez comme nous avec des robes de chambre, et qui y vendoient des couteaux mais autrement faits que les nôtres.

The mention of fortresses by the sea reminds one of what Assiniboin Indians are reported to have said to De Noyon in 1688. Le Sueur, however, is here speaking of the Sioux whose language he knew well, so that is no question of his having misunderstood his informants. Since it is quite obvious that the Sioux could not have reached the Pacific in fifteen days or seen fortresses on the seashore, we must conclude that these Indians like the Assiniboin, inserted in their accounts legendary native lore concerning the West.

After quoting these texts which led him to believe that there was " une mer à l'ouest de la Rivière de Mississipi et pas éloignée des peuples qui nous sont connus, "Delisle answers an objection which he had touched upon in the draft of his memoir. ${ }^{45}$

43. The inscription on Louvigny's map says: "Cette riuiere tombe a la mor de louest dans la mer Vermeille. 》

44. This river is marked on the map of 1703 .

45. In Preuves du voisinage... ASH, 115-11: no. $12 \mathrm{C}$. 
Que l'on ne dise pas que cette mer soit la mer Vermeille de Californie, et que c'est là que cette Rivière d'ouest se doit décharger, comme le croyent la plûpart de ceux qui en parlent, car c'est faute d'avoir examiné les distances et les observations qu'ils parlent de la sorte.

M. de la Salle lui même croyoit bien autrefois que la Rivière de Mississipi se rendoit dans cette mer de Californie, et le Sr. Jolliet a cru que c'étoit des peuples de Californie de qui venoient les haches dont j'ai parlé ci-dessus.

Mais il dcit y avoir plus de 400 lieues de" cette Rivière de l'ouest jusques à ladite Mer, et l'on voit bien que ce n'est pas de la même dont parlent les Sauvages, ni avec ceux de Californie qu'ils trafiquent.

What he says about the distance between the River of the West and the Gulf of California is quite true; it is also true that the sea spoken of by Assiniboin, Sioux, or Ottawa Indians is not the Gulf of California; but neither was it a sea such as Delisle conceived to exist not far from the Mississippi. When he wrote this memoir, he had not seen the letter of Vaudreuil and Bégon which relates that the Assiniboin Indians had told De Noyon that the journey from their country to the Sea of the West would take two and a half months; nor had he seen the memoir of Cadillac in which the distance to that sea was said to be one hundred days' travel. Guillaume Delisle, however, had seen these documents when he copied his father's memoir for presentation to the minister, but made no mention of them and simply repeated that the Sea of the West “ n'est pas éloignée des peuples qui nous sont connus. "

Peut-être voudra-t-on sçavoir quelle route il faudroit tenir, pour faire cette découverte avec plus de certitude. A quoi je réponds que si on alloit par le Canada il semble que le Rivière des Ozages ou de Missouri seroit la route la plus sûre, sur tout en prenant langue des Aouia [Iowa] qui connoissent, dit M. de Louvigny, une Nation qui trafique sur cette mer, et consultant encore les Panis chez lesauels Mr le Sueur m'a dit qu'il y avoit des François qui vivaient parmi eux à la source de cette Rivière de l'ouest.

Que si l'on venoit par l'embouchure du Mississipi, il faudroit se rendre aux Cenis, parmi lesquels du tems de M. d'Iberville il s'étoit retiré des Espagnols, les uns blancs, les autres mulâtres chassés de Quivira par les Sauvages.

Although Delisle had spoken of a "Rivière de l'ouest " marked on Louvigny's map, and although he had learned from Le Sueur of a " grande Rivière nommée Meschasipi " with its course toward the 
west and had marked it on his own map of 1703 , he considered the Missouri route the best of all. This is not surprising, for he was aware of what Marquette, Jolliet, and Membre had written; and he never doubt that what Marquette and Membré said was the truth.

When he wrote his memoir he had seen Lahontan's book. In it there is a description of the Long River, which he also marked on his map of 1703. ${ }^{4}$ The geographer, however, was skeptical with regard to the reality of this discovery as the inscription inserted in his map testifies:

a La Riviere Longue ou Riviere Morte a eté découverte depuis peu par le Baron de Lahontan jusqu'a l'endroit qui est marqué dans la Carte ce qui est plus à l'Occident a été dessiné sur des peaux de cerf par des Sauvages de la Nation des Gnacsitares a moins que le dit Sr de Lahontan n'ait inventé toutes ces choses ce qu'il est difficiles de resoudre étant le seul qui a pénetré dans ces vastes contrées. ")

We know that Lahontan had invented his Long River; and even those who are inclined to think that the baron went up the Minnesota must admit that the course of this river, especially the upper reaches, bears no resemblance with his description of it.

In a memoir published in the Mercure de France for May 1754, M. de la Grange de Chézieux undertook to defend the veracity of Lahontan. ${ }^{47}$ In it, he took Charlevoix to task for having called the discovery of the Long River a fabulous tale; this, says our apologist, is a gratuitous insult, for " le baron de Lahontan était officier, il etait gentilhomme. "What Chézieux probable did not know was that his " officier " would be a disgrace in any army. In 1699, four years before the publication of his book, this French "gentilhomme " was writing to the Spanish Duke of Jovenazo inciting this foreigner against his own country. ${ }^{48}$.

"M. de l'Isle ", Chézieux tells us in a scandalized tone, " dans sa carte du Canada avait placé la rivière Longue, il l'a supprimé dans sa carte du Mississipi, sans en dire la raison. " ${ }^{49}$ This second map is

46. Nouveaux Voyages de Mr.le Baron de Lahontan dansl'Amerique Septentrionale (2 vols., The Hague 1703), 1: 136-185.

47. J.-E. Roy reprinted the article in a Laron de Lahontan, "Proceedings and Transactions of the Royal Society of Canada, 1st serie, 12 (1894), section 1, 132-140.

48. The Journal of Jean Cavelier (Chicago 1938), 48 and 134, note 4. 
that of 1718. By this time Claude and Guillaume Delisle had received information from men who had traveled in the West, men who knew that there were no "Esanapes, " " Gnacsitares, " and other fantastic tribes mentioned by Lahontan as living in that region. Neither Claude nor Guillaume were willing to compromise their reputation by accepting the mythical Long River, just because Lahontan " était officier, il était gentilhomme. ") Sometime in 1714, they received a copy of a letter of M. Lemaire, written at Pensacola on January 15 of that year, ${ }^{50}$ from which both Claude ${ }^{51}$ and Guillaume ${ }^{52}$ had made extracts of different parts. In the extracts made by Claude occurs the following passage: "On regarde dans ce pays comme des contes faits à plaisir ce qu'on lit dans le baron de Lahontan de cette partie occidentale de la Louisiane, et il faut attendre que celle cy soit plus peuplée de françois pour qu'on puisse decouvrir ce qui nous est inconnue de ce pays là. " On March 15, 1716, M. Bobé wrote to Guillaume Delisle: "Would it not be well to efface that great river which Lahontan says he discovered? All the Canadians, and even the Governor-General have told me that this river is unknown; if it existed the French who are in the Illinois and at Ouabache would know of it. $)^{53}$

We said at the end of the first part of this article that when Cadillac brought his memoir to Paris in 1699, France was on the eve of the War of the Spanish Succession, which began in 1701. The hostilities spread to the colonies, and in Canada the French were far too busy fighting the English in the east to have much time to continue their search for the Sea of the West. There is, however, evidence that in the midst of the turmoil, the authorities in New France had not lost sight of that elusive sea.

In one of the "letters " of Antoine Denis Raudot, the intendant of Canada from 1705 to 1710 , mention is made of the Sea of the West. ${ }^{54}$

49. Roy, loc. cit., 136.

50. AC, C 13C, 2: 109-138, translated into English from another contemporary copy in Mid-America, 19 (1937): 128-154.

51. ASH, 115-32: no. 4.

52. ASH, 115-10: no. 22 B.

53. Bobé to Delisle, March 15, 1716, in Historical Magazine, 3 (1859): 232.

54. On the authorship of these "letters ", cf. Frontenac and the Jesuits, 65 note 44; " Last Voyages and Death of Louis Jolliet, " RAPQ, 1944, p. 185, note 72. From internal evidence, the letter were composed in 1709 and 1710. 
Speaking of the Assiniboin, he says that these Indians have assured the few Frenchmen who had gone to their country,

qu'à huit journées de chez eux, jl y a une grande rivière qui sort du lac qui porte leur nom et qu'elle va et vient touts les jours, ce qui s'explique par le flux et le reflux, qu'ils ont veu plusieurs fois de grands canots à la voile dessus, ce sont des navires, mais que les peuples qui sont dans ces grands canots ne traitent pas avec eux, et les tuent quand ils les peuvent attraper; que cependant ils sont faits comme nous.

Ces sauvages ont apparemment pénétré jusques à la Mer de l'Ouest, il y a apparence que les peuples dont ils parlent sont des Espagnols..$^{55}$

A reading of the eighty-nine letters makes it also apparent that Raudot had only very vague ideas about the geography of the West, with Indians living in that region, on the shores of Hudson Bay, or with the Eskimo. He relied on relations of travelers and did not always use them to the best advantage. ${ }^{56}$ " On auroit trouvé cette mer, si ceux qui avoient eu ce dessein n'avoient pas esté arrestez en chemin par le profit qu'ils trouvoient dans le commerce du castor; outre qu'un particulier seul ne peut faire cette entreprise. " We have not found what attempt to reach the Sea of the West Raudot is alluding to in this passage. There had certainly not been any government sponsored expedition at this date. It may also be that he is alluding to Le Sueur; but this trader and explorer never set out to find the Sea of the West and confined his activities to the Sioux country.

" Elle seroit cependant aisée, et on pourroit la faire en passant chez les Sioux ou les Assinipouals, ou par le Missouri qui est une grande rivere qui va toujours à l'ouest. Il est certain suivant le rapport de tous les Sauvages qu'on pénétreroit chez des peuples policés comme nous, ou mesme dans la Chine, comme quelques uns le prétendent. ") It is clear that it was not the Indians who contended that China lay beyond the Sea of the West, this was the contention of the French. Elsewhere speaking of the great western tributary of the Mississippi, he observes: "Les nations qui l'habitent disent qu'elle vient d'un grand lac qui a encore sa descharge d'un autre coté, ce qui pourroit faire connoître qu'elle tombe dans la mer de l'ouest. ") ${ }^{57}$

55. MARGRY, 6: 14.

56. Cf. "Last Voyages and Death of Louis Jolliet, " RAPQ, 1944, p. 195-197. 
Further evidence of the interest in the Sea of the West by French officials in Canada is found in Nicolas Jérémie's Relation. This man, who had gone to Hudson Bay with Iberville in 1694, remained at Fort Nelson, or Fort Bourbon as it was called by the French, until the Treaty of Utrecht. He was commandant of the post from 1709 until 1714, when he received orders from Paris to hand the place over to the English. He went first to Canada, and then to France where he wrote his Relation semetime in 1715 . Bobé, who received a copy of it from Raudot, wrote to Guillaume Delisle about the description of the country west of Hudson Bay: "Si L'auteur avoit été plus habile geografe, ce qu'il dit ne seroit pas difficile a Comprendre, il y parle Clairement et comme d'une chose sure d'une Communication de la Baye d'Hudson avec la mer de l'Ouest. " 58 The passage mentioned by Bobé reads as follows:

Je ne dirai rien de positif des Remarques que l'on peut faire, en continuant le long de la Mer vers le Nord, sinon que nos Sauvages rapportent que dans le fonds de cette Baye il y a un Détroit où l'on découvre les terres facilement d'un bord à l'autre. Ils n'ont pas encore pénétré jusqu'au bout de ce Détroit: Ils disent qu'il y a des glaces toute l'année, que les courans transportent tantôt d'un côté, tantôt de l'autre. Suivant toutes les apparences, il est à croire que ce bras de Mer a communication avec la Mer de l'Ouest; $\&$ ce que donne lieu à cette conjecture, c'est lorsque les vents dépendent du Nord, la Mer dégorge par ce détroit en si grande abondance, que l'eau augmente dans toute la Baie d'Hudson quelquefois de dix pieds à pic plus que son cours ordinaire..$^{69}$

This strait, which Delisle represents on his maps of 1720 and 1722, seems to be the same as that which Renaudot vainly attempted to pass through after the taking of Fort Nelson in $1694 .{ }^{60}$ If this surmise is

57. C. DE Rochemonteix, ed., Relation par lettres de l'Amerique Septentrionalle (Paris 1904), 166.

58. Bobé to Delisle, July 2, 1717, ASH, 115-10: no. 26 D. - Delisle saw this relation at a later date and inserted the geographical information of the country west of Hudson Bay on several of his drafts (AN, JJ, 75-127a and 1702, 178-1-14; BN, Estampes, Vd 22), but he eliminated some details from his published maps of 1720 and 1722 .

59. "Relation du Detroit et de la Baie d'Hudson, " in Relations de la Louisiane et du Mississipi, J.F. Bernard, publ. (Amsterdam 1720), $11 \mathrm{f}$. 
correct, it shows that, in spite of lack of success, Jéremie still clung to the hope of reaching the Sea of the West by means of some waterway connecting it with Hudson Bay.

" Les Sauvages disent, qu'après avoir marche plusieurs mois à l'Oüest-Sud-Oüest, ils ont trouvé la Mer sur laquelle il ont va de grands Canots (ce sont des Navires) avec des hommes qui ont de la barbe \& des bonnets, qui ramassent de l'Or sur les bord de la Mer (c'est-à-dire, à l'embouchure des Rivieres). ") Several month's march to the west-southwest from the shores of Hudson Bay would not have brought the Indians anywhere near the Pacific. The only reason for giving this quotation is by way of contrast with what Jérémie says later on in his Relation. It must be further observed that whenever he reports what the Indians of the Hudson Bay region told him, we may accept his word for it, for he knew their language, being the official interpreter at the post.

After describing the inland hydrography of the country west of Hudson Bay as reported to him by the Indians, and after speaking of a lake in the country of the Assiniboin, Cree, and Saulteurs, called Ouehipigouchib or small sea, he goes on to say:

A son extremité il y a une Rivière qui se décharge dans un autre lac que l'on nomme Tacamamiouen. Il n'est pas si grand que les autres. C'est dans ce Lac que se décharge la Riviere du Cerf, qui est d'une si grande 6tendue, que nos Sauvages n'ont pas encore pâ aller jusqu'à sa source. Par cette Riviere, on peut aller joindre une autre Riviere qui porte du côté de l'Ouest au lieu que toutes celles dont je viens de parler, ont leur décharge, ou dans la Baye de Hudson, ou bien dans la Riviere du Canada [St Lawrencel. J'ai fait tout mon possible pendant le temps que je suis resté au Fort Bourbon, pour envoyer des Sauvages de ce côté-là, sçavoir s'il n'y auroit point quelque Mer dans laquelle se decchargeât cette Riviere; mais ils ont la guerre contre une nation que leur barre ce passage. J'ai interrogé des prisonniers de cette Nation, que nos Sauvages avoient amenez exprès pour meles faire voir. Ils m'ont dit avoir guerre avec une autre Nation beaucoup plus éloignée qu'eux dans l'ouest. Ceux-là disent avoir pour voisins des hommes barbus qui se fortifient aveo de la pierre, \& se logent de même; usage que les Sauvages n'ont point. Ils disent que ces hommes portant barbe, ne sont point habillez comme eux, \& qu'ils se servent de chaudieres blanches. Je leur

60. Supra, 378. 
montrai une tasse d'argent, \& ils me dirent que c'étoit cela même dont les autres leur avoient parlé. Ils disent aussi que ces gens-là cultivent la terre avec des outils de ce metal blanc. De la manière qu'ils dépeignent le grain que ces gens cultivent il faut que ce soit du Mais. ${ }^{61}$

All of this is very complicated. The Indians of Hudson Bay are at war with other Indians, who in turn are at war with still another nation farther west, and it is these who said that they had bearded men as neighboors. It is also very vague. From the context, these bearded men who live in stonehouses were located west of Hudson Bay. If the Indians had said that the direction was west-southwest, one might possibly recognize the Spanish settlements of New Mexico of which they might have heard in this roundabout way, but these settlements were not near the sea. The recognition by the Indians of the metal which the bearded men used to make their tools should not be taken too seriously, for it is well known that they were willing to recognize anything which they saw the white men wanted to recognize.

Pendant que j'étois à Québec il y a 4 ou 5 mois, M. Begon Intendant de Canada, me fit l'honneur de m'envoyer querir, pour que je lui donne les connoissances que j'avois de ce Païs-là, pour faire entreprendrecette découverteparle Canada. Mais je crois qu'elle seroit beaucoup plus facile par les route que je viens de marquer si nous possedions encore le Fort Bourbon, en ce que le chemin seroit beaucoup plus court, \& que ce sont presque toujours de beaux Païs, où l'on ne manqueroit point de chasse,... outre les fruits qui y viennent sans les cultiver. ${ }^{62}$

It is clear from this passage of Jéremie's Relation that Michel Bégon, who had been intendant of New France since 1712, was interested in finding a route to the Sea of the West. But at the time such a search was out of the question. After the Treaty of Utrecht, the French government had ordered to fortify Cape Breton Island. In October 1714, Vaudreuil, the governor of New France, and Bégon, went to the place that was to be Louisbourg. Instead of returning to Quebec Vaudreuil went to France where he remained until 1716. We do not know whether the latter tried to interest the authorities in France in

61. "Relation du Detroit et de la Baie d'Hudson, „ibid., 26 f.

62. Ibid., 27. 
the discovery of the Sea of the West, but we know that he spoke to Bobe who was very much interested in finding that sea; and we also know that shortly after his return to Canada, Vaudreuil and Bégon sent a memoir to Paris, in which a river leading to the Sea of the West was described.

Joined to the memoir of November 12,1716, was a curious document containing the ways and means to reach the sea. "Le transport des marchandises, qui se feroit en canots depuis la mer de l'Ouest jusqu'au lac Superieur, les rivières estant fort navigables. " How Vaudreuil and Bégon knew this is not said, any more than what followed: "Cette navigation seroit courte, eu égard à celle que les vaisseaux font d'Europe pour y aller. " This was quite true, for in those days it meant rounding the Horn and sail north some 100 degrees. "Pour parvenir à cette découverte, il est nécessaire de commencer à établir, dès à présent, trois postes, un à la Rivière de Kamanistigoya dans le Lac Supérieur, un autre dans le Lac des Christinaux, et le troisième dans celui des Assinipoiles. "

The first objective of these posts was to wean away the Indians and prevent them from trading with the English established on Hudson Bay. This appeared so important that Vaudreuil intended to sent men in April 1717, to found the first post, and, if possible, the second. Once the three posts established, " on pourroit tenter la découverte de la mer de l'Ouest,... ce qui se feroit de celuy des Assinipoiles par un petit nombre de François qu'on pourroit y envoyer avec les Sauvages qui vont à la mer, afin de ménager la dépense. "

On February 3, 1717, these memoirs were examined by the Conseil de la Marine. The establishment of the three posts was approved, but they wanted to know how much it would cost " pour continuer cette découverte en la réduisant au meilleur marché, et qu'il envoye le projet le plus en détail qu'il pourra, de mesme que celui de la dépense qu'il y aura à faire. " ${ }^{6} 3$ It was already too late. Vaudreuil had said that he was sending an officer in April, and in fact La Noue went to Kaministikwia.

Finding the Sea of the West was also talked about in Louisiana, as appears from a memoir of October 1717, written by Hubert, the commissaire ordonnateur of the southern colony. To find mines, he

63. Margry, 6: 501-503. 
says, one must go to the mountains where the Missouri has its headwaters:

Ce projet, très facile à exécuter, et qui semble ne devoir pas estre reculé, crainte d'estre prévenus, a encore une branche qui n'est pas moins magnifique, e'est une grande rivière qu'on prétend qui sort de la mesme montagne, où est la source du Missouri, On croit mesme que c'est une branche qui va tomber dans la mer de l'Ouest. Cette descouverte, les Canadiens qu'on y mèneroit l'auroient bientost faite, et par l'establissement, qui procureroit le commerce aveo la Chine et le Japon, le chemin en seroit court. ${ }^{64}$

From the account of those who have ascended it, Hubert depicts the country traversed by the Missouri, the woods, the game, the amiable character of the Indians. The only difficulty is the expense which is negligeable, for it will not cost much in a country that is so fertile as that of the Missouri to feed and support one hundred and fifty men.

Hubert was merely echoing what was being said in Louisiana at the time. M. Lemaire, a priest of the Paris Missions Etrangères, was born on January $21,1674 .{ }^{65} \mathrm{He}$ had written several memoirs on Louisiana before the one with which we are concerned, that dated March 7, 1717. ${ }^{66}$

M. Lemaire begins by giving the boundaries of Louisiana, and treats of its discovery and exploration; following which is an enumeration of the ports, the mines not yet discovered, but which were certainly there. A whole section is entitled: " Des principales Rivieres de la Louisiane." He then reports rumors heard from Indians by Frenchmen who had ascended the Missouri, and tries to make them fit in with what Lahontan had said about the river, but especially with what he read in the book of Gonzalez de Mendoça. At present, all that can be expected, he says, is to wait until Louisiana is more

64. M ARgRY, 6: 189.

65. Cf. Mid-America, 19 (1937): 154.

66. BN, Mss, fr., 12105: 1-12. - In the following year he wrote to Paris: ( J'ay pris la liberté l'année passée d'envoyer ce Memoire accompagné de plusieurs Cartes au Conseil Royal de Marine; et je ne scay comment il est arrivé que j'ignore encore s'il a esté présenté. Il m'est seulement revenu qu'il a esté ardemment souhaitté par led. Conseil qui en avoit eu quelque avis, je l'ai retouché depuis, et même augmenté notablement en quelques endroits qui mont paru le plus interesser la Cour et les sçavants. " AC, C 14C, 2: 153. 
populated. "Alors on sera en estat de tenter ces decouvertes aussi bien que celle de la Mer de l'ouest, sur laquelle à l'occasion du Missouri, qui est la Riviere la plus propres par laquelle on puisse faire tenter sa decouverte; je feray icy une courte digression pour la satisfaction des Curieux. " In spite of what he says, this digression is much too long to be reproduced in extenso.

On entend communément par la mer de l'Ouest, celle qui dans l'hemisphere Septentrional de la Terre, est interposée entre la partie la plus Orientale du Nord de l'Asie, et les plus occidentale de l'Amerique la plus Septentrionale; ou, pour m'expliquer en d'autres termes, celle qui baigne a l'Ouest, les costes de l'Amerique qui est le plus au nord. Ainsi chercher la mer de l'Ouest, c'est chercher l'extremité du Continent de l'Amerique Septentrionale, du costé de l'Ouest ${ }^{67}$.

The whole question was how far was that " extrémité ", and what was the shortest way to it. It is probable, says Lemaire, that the Spaniards have some knowledge of that sea, " mais par politique et pour derober cette connoissance aux autres Nations, ils continuent d'agir comme s'ils ne l'avoient pas. Peut estre aussi qu'ils n'en sçavent pas plus que nous la dessus, leur coutume estant, en partant d'Acapulco pour les Philipines, de cingler en pleine mer a l'Ouest, et non de cotoyer la Californie. ")

Having supposed what this sea was, the question is how to get there; for this there were three ways: two by sea and one by land. The first would be to penetrate the Vermilion Sea, " ou en cas que cette mer n'eut pas d'issue par le nort, comme je le crois avec $\mathrm{Mr}$ De Lisle en cottoyant la coste occidentale de la Californie et ce qui est par dela de la coste occidentale de la grande terre de l'Amerique. " ${ }^{68}$ But, he adds, " les Espagnols ne seroient pas d'humeur a le permettre". The second route by sea is by way of one of the numerous bays which are in northern Canada and which link Hudson Bay with the Sea of the West; but this route is " presque impraticable, a cause des glaces et froids insupportables de ces quartiers. Peut estre pourtant qu'on pourroit surmonter ces difficultez en choisissant bien son temps, pour traverser ces Bayes ».

67. BN, Mss. fr., 12105: 8

68. AC, C 13C, 2: 162 . 
" La 3e voye qui est par terre, est de traverser les terres qui sont a l'Ouest de la Louisiane superieure ou septentrionale. " It is to be remarked, however, that the more one would ascend the less one would have to travel, but one would expose oneself to great difficulties on account of cold and ices.

Il faut prendre un milieu raisonnable, et ce milieu seroit de chercher cette mer, en commençant sa route à l'Ouest par la hauteur des $45,46,47$, ou $48 \mathrm{~d}$ on s'eleveroit facilement a cette hauteur, en remontant le Missouri et le Mongona, jusqu'a leurs sources, et quand on seroit arrivé, il s'agiroit alors de chercher quelque Riviere navigable qui eut son cours a l'Ouest ou au Nord ouest pour s'y embarquer et la suivre. Il est presque indubitable qu'une telle Riviere estant une fois trouvée, ou elle conduiroit a la Mer de l'Oiesest, ou du moins dans quelque autre Riviere ou lac qui auroit sa décharge a l'Ouest; et ainsi de Riviere en riviere on tomberoit enfin dans cette mer.

He then comes to what he had said about the discovery of La Salle. The easiest way would be to go to the northeast,

car il y a longtemps que des Nissipissingues, nation qui habite dans le Canada sur un lac du même nom, ont fait des courses par terre a l'Ouest jusqu'à cette mer, sur laquelle ils assurent avoir veu des batimens à voile; Or il n'est pas vraisemblable qu'ils eussent rencontré cette mer, ou ils disent l'avoir rencontrée, si cette coste ne faisoit a peu pres ce Rhumb de vent.

At the end of his digression, M. Lemaire strikes a note quite different from that struck in all the other memoirs. As we have seen, the main object of this discovery was to find a short cut to China and to the Far East.

J'avoue de bonne foy que je ne comprends pas bien l'avantage qu'on tireroit de cette decouverte de la Mer de l'Ouest par les terres. Je trouve dans cette recherche plus de curiosité que d'utilité; et quand je pense que, tout bien supputé, il y a des environs des sources du Missouri, jusqu'à la terre d'Asie la plus orientale, quelques 1440 lieues d'espace compris tant de terre que de mer; a quoy il faut adjouter Le chemin du Missouri a l'Isle Dauphine, et de l'Isle Dauphine en France, je crois qu'une telle route ne feroit par diminuer le prix des Marchandises qui nous viennent des Indes Orientales. 
M. Bobé, one of the king's chaplains at Versailles, was another of these men very much interested in the discovery of the Sea of the West. It should be noted, however, that this man never came to Canada and that he was a Lazarist, not a Jesuit. In a letter to Guillaume Delisle, he says: " Mr Raudot admits that it is easy and advantageous to discover the Western Sea. I press him strongly to have the discovery made. " " ${ }^{9}$ In another letter to Delisle, he says:

They tell me that among the Scioux, up the Mississippi; there are always Frenchmen trading; that the course of the Mississippi is from North to West, and from West to South; that it is known, that towards the source of the Mississippi, there is, in the highlands, a river that leads to the Western Ocean; that the Indians says that they have seen bearded men, with caps who gather gold dust on the seashore, but that it is very far from their country, and that they pass through many nations unknown to the French.

I have a memoir of Mr. La Motte Cadillac, formerly governor of Missilimackinac, who says that if St. Peter's River is ascended to its source, they will according to all appearance, find in the highlands another river leading to the Western Ocean.

For the last two years I torment exceedingly the Governor-General, Mr. Raudot, and Mr. Duché to induce them to discover this Ocean. ${ }^{70}$

From the above, M. Bobé was somewhat acquainted with the literature of the subject, for as early as 1716, he had in his possession the relation of Lamothe Cadillac. The governor general was Vaudreuil who, as we have seen, went to France in 1714; and the Raudot, was Nicolas-Denis, former intendant of New France, who had written the Relation par lettres. In the following year, he had " received depuis peu ", from Raudot, " une Carte de La Baye d'Hudson et une grande relation des payis qui sont à l'ouest du fort Bourbon faite par Le Commandant de Ce fort qui a demeuré dix ou douze ans dans ce quartier La, " which he intended to communicated to Delisle, should the latter wish it.

J'ay mandé mes reflexions sur tout cela à Mr. Raudot et sur la Mer de l'ouest que l'on trouvera entre le 44e et Le 48. degré, si on descend plus bas que le $44 e$ on trouvera La californie, si on monte plus haut que le $48 \Theta$ ou $50 e$ degré on trouvera toujours des terres jusqu'à

69. Bobé to Delisle, January 8, 1715, in Historical Magazine, 8 (1859): 231.

70. Bobé to Delisle, March 16, 1716, in Historical Magazine, 3 (1959): 232. 
la Tartarie moscovite, et c'est par Cet endroit que Les Etats du Czar touchent à l'Amerique et que Les Tartares et des Israelites de La dispersion faite par Salmanasar ont passé dans l'Amerique Septentrionale et L'ont peuplée, Les mœurs, Les manieres, les Coutumes, et plusieurs autres choses me convainquent que Ces peuples, descendent des Tartares et des Israelites.

Quand j'en auray Le tems j'ay envie de travailler à une dissertation sur ce sujet Laquelle j'auray L'honeur de vous Communiquer et que je vous prierai de Corriger, persuadé que je suis que vous avez infiniment plus de Lumières que moi et que qui que ce soit sur ce sujet. ${ }^{7}$

It is evident that Bobe intended to write a memoir on the Sea of the West, and that he intended to insert in it his theory about the origins of the Indians. " J'ay vu icy Mr. Raudot qui m'est Venu voir ", he wrote in another letter to Delisle, "il m'a dit qu'il y a un an que l'ordre est donné pour faire La découverte de la Mer de L'Ouest ". ${ }^{72}$ In another letter to Delisle, he asked for his hemisphere septentrionale and his map of New France, he will mark on them his ideas concerning the Sea of the West. "Il est certain qu'il n'y a point de detroit qui vienne de la Baye d'hudson dans la mer du Sud ouest mais bien un qui a Communication de la baye d'Hudson avec la mer du Nord Ouest au dessus du pays que j'appelle Bourbonie ".$^{73}$

Consequently, it was not surprising to find him writing to Delisle: a Je finis un memoire sur la mer de l'Ouest \&c, different du votre, si j'osois je le Communiquerois a l'Academie ".${ }^{74}$ Fourtunately, he did not dare send his memoir to the Académie des Sciences; nor did Delisle for that matter, although the latter's was decidedly better. When Delisle sent communications to the Academie, they were ordinarily based on facts; here, however, was a theory based mostly on that could not be proved or disproved except by explorations. These explorations (Mackenzie, Lewis and Clark) were to show that the width of the American Continent was much greater than Delisle and Bobe ever thought. "Je n'ai pas encore envoyé ma carte a Mr. Raudot",

71. Bobé to Delisle, July 2, 1717, ASH, 115-10; no 26 D.

72. Bobé to Delisle, October 16, 1717, ASH, 115-10: no 26 F.

73. Bobé to Delisle, January 4, 1718, ASH, 115-10: no. 26 G.

74. Bobé to Delisle, April 30, 1718, ASH, 115-10: no $26 \mathrm{~J}$. 
wrote Bobé one month later " mais je La Luy ay promise, et je Luy ai déjà envoyé Le Memoire que j'ay fait touchant La mer et Les payis de l'Ouest "). 75

A few months later, he again wrote to Delisle, having seen in the meantime two memoirs of the geographer; namely, one in which Delisle, on better ground, commented on the course of the Mississippi from its mouth to the Falls of St. Anthony, and the other, his memoir on the Sea of the West.

Un Cours du Miciscipi aussi Exact que celuy de La seine Est une piece des plus curieuses aussi bien que la Carte et La [sic] memoire que vous avez presentées pour prouver L'Existence et la Scituation de La mer de l'Ouest, J'ay bien de la joie de L'honneur que Cela vous a procure, que le Conseil [̣de la Marine] goûte ce que vous Luy avez proposé, et qu'il paroisse avoir inclination pour La decouverte de Cette mer.

Le brouillon du memoire que j'ay présente à $M$. Raudot est si mal Eorit et si barbouillé que vous ne Le pouriez peut etre pas Lire, Cependant je vous L'Enverrois si je sçavois qu'il put vous Etre Utile. ${ }^{78}$

It seems that Bobé did send his memoir, for we read in another letter of his:

$J_{\theta}$ vous prie de me dire sincerement votre sentiment sur mon memoire touchant La mer de L'Ouest dans Lequel je ne doute pas qu'il y ajt bien des choses à Corriger, je voudrois bien vous envoyer une Carte de ces payis, comme je me La suis imaginée, mais je n'ai pas Les instrumens necessaires pour y marquer Les Latitudes et Les Meridiens. ${ }^{77}$

It would be a waste of time to analyze this memoir, for it contains nothing with which we are not already familiar. It is full of assumptions, of theorizing; he speaks of the descent of the Indians from the "Israelites tartarisés "; of the Strait D'Uriez; of the nonexistence of the Strait of Anian; etc. Bobé believed that by putting to_contribution Father Louis Hennepin, Sieur Antoine de Lamothe

75. Bobé to Delisle, May 27, 1718, ASH, 115-10: no $26 \mathrm{~K}$.

76. Bobé to Delisle, [after July 9, 1718], ASH, 115-10: no. 26 A.

77. Bobé to Delisle, August 16, 1718, ASH, 115-10: no 26 N. 
Cadillac, Sieur Nicolas Jérémie, Sieur Alexandre Turpin, and finally " le beau memoire " of M. Lemaire, " qu'il a envoyé à la Cour l'année derniere 1717. Ces idées doivent être bien plus justes que celles que lon auoient il y a 50 ans parce que l'on connoit presentement bien des pais a l'ouest que l'on ne connoissoit point alors. ") ${ }^{78}$ We have seen what to think of four of the authorities, as for the fifth, here is what Bobé has to say about him:

Le Sieur Alexandre Turpin dont ie parle en plusieurs endroits de ce memoire est un Canadien de Montreal qui a beaucoup voiagé dans le canada chez les Islinois sur le Misiscipi et dans la louisiane et qui a passé deux hiuers au fort le sueur sur la Riuierre St. pierre, laquelle il a Remonté 40 Lieuës depuis 4 ans que je suis en Commerce de lettres auec luy, ie luy ai fait quantité de questions auxquelles il m'a repondu exactement selon ce qu'il a vu, et ce qu'il a appris des voiageurs françois et des sauuages d'ou j'ai tiré beaucoup de Lumieres desquelles je me suis serui utilment pour faire ce Mémoire.

Besides this identification, we are told what the Indians said to Turpin: the rivers beyond the Mississippi have their course toward the west; and "le sieur Turpin me mande encore qu'il croit que la Route par le riuiere st. pierre est les plus aisée pour aller a la mer de l'ouest, et je pense qu'il pourroit bien auoir raison ".

If Bobe expected us to take him seriously, he should have made an effort to present his arguments to the best advantage.

Pour prouver Lexistence et la situation de la mer de L'ouest je n'ay point recours à ce que les sauuages du Canada disoient aux francois il y a plus de 60 ans Car depuis ce tems là on a decouuert bien du pais à l'ouest on n'a point encore de Connoissance certaine de la Mer, laquelle cependant on Connoitroit depuis lontemps si elle eut été aussy proche que disoient autrefois les sauuages, ils vouloient parler des Jacs de la baye d'hudson, et du golfe mexique dont ils avoient entendu faire Recit par d'autres sauvages.

In the various route " pour aller a la mer de l'ouest, " he speaks of all those which he knows, or thought he knew. The first is that of the Mississippi. "Une seconde route c'est de Remonter la Riuiere de Missoury ou celle de Monigona ou bien celle de St. Pierre enfin

78. The memoir will be found in AC, C 11E, 16: 40-64; a contemporary copy is in the third volume of "A la Substitution du Valdec proche Soleure en Suisse ", 109-199; printed in Bulletin des Recherches historiques, 38 (1932): 475-496. 
celle qu'on voudra et qui sera commode par rapport au lieu d'ou l'on partira soit du canada soit de la louisiane ". The third route to reach the Sea of the West is that of the country between New Mexico and the Missouri; the fourth is that of the Rio Colorado. " Je repette encore une fois que je croy que c'est de cette rivierre Colorado de cette baye ou lac, et du golfe de Californie dont les sauuages ont parlé au pere marquet aux sieurs jolliet et la hontan et a plusieurs autres francois "). The fifth route is the most sure and the shortest, that of the Kaministikwia, for they will certainly find other rivers which flowed towards the west. Finally the sixth route: " Etant chez les Assinipoels si on dirige sa route a l'ouest apres auoir fait quelques centaines de lieues par de belles et vastes plaines et prairies on trouvera des Riuierres d'espace en espace qui aiant leur sources dans le Nord de la bourbonie vont se rendre dans la mer meridionale de la bourbonie, en s'embarquant sur ces riuierres on tombera dans cette mer ").

" J'espère que ceux qui prendront la peine de lire ce memoire ", he says toward the end, " auoueront que j'ai prouvé tout ce que j'avois entrepris de persuader a ceux a qui je prends La Liberté De le presenter "). The only thing that he proved is that he had a lively imagination. This memoir is of interest for two reasons; first, because, although we know nothing about him, we know that he was in correspondence with Guillaume Delisle; and second, because of the date when it was first sent to the Court.

As is well know, two years later Charlevoix was sent to find out everything he could about the Sea of the West. " Le Roy a chargé, Messieurs, le Pere de Charlevoix, qui vous remettra cette depesche, de la decouverte de la mer de l'Ouest, et l'intention de sa Majesté est que vous luy permettiez de monter dans les pays d'en haut avec deux canots et huit voyageurs. Les marchandises qu'ils porteront et dont ils feront commerce serviront à les indemniser des despenses qu'ils feront pour ce voyage $)^{79}$. As for Bobé he heard of this indirectly. Two weeks later he wrote to Delisle: "Un Jesuite est parti de Paris en poste pour aller en Canada faire la decouverte de la mer de l'ouest. La cour voulant que cette decouverte se fasse incessament non par la Louisiane, mais par le Canada, par le Lac Superieur et par celuy de

79. Minister to Vaudreuil and Bégon, June 7, 1720, AC, B 42: 448. 
Tacamamiouen. Je vous en ferois voir une carte quand vous serez icy. ") 80

The departure of Charlevoix brings to a close one period the longest - of the search for the Sea of the West. Since the day of Cartier, one explorer after another had tried to find a short cut to the Far East. Now, after nearly two hundred years, the government was again investigating the possibilites of a westward route; but when Charlevoix returned, it was no longer interested in finding a route to the Sea of the West.

Jean Delanglez, s.j. Loyola University, Chicago.

80. Bobé to Delisle, June 21, 1720, ASH, 115-16: no. 4. 